Ks. Norbert WIDOK ${ }^{*}$

\title{
LIST DO RZYMIAN W KATECHEZACH CYRYLA JEROZOLIMSKIEGO SPOSOBY WYKORZYSTANIA I INTERPRETACJI
}

Cyryl Jerozolimski, wygłaszając katechezy do katechumenów oraz do nowo ochrzczonych, pozostawił ważne świadectwo sposobu przekazywania kerygmatu wiary, mające miejsce w 2 . poł. IV w. w Jerozolimie - mieście aktów zbawczych dokonanych przez Jezusa Chrystusa. Treść katechez ukazuje czytelnikowi metodę nauczania o prawdach wiary połączonych z wykładnią wymogów moralnych wynikających z zasad Ewangelii. Na podstawie lektury tych katechez łatwo zauważyć, że ich struktura tematyczna została oparta na tzw. symbolu jerozolimskim, a argumentacja teologiczna zastosowana przez Cyryla opiera się głównie na tekstach biblijnych. Warto zatem wniknąć w ich treść i dokonać porównawczych analiz co do wykorzystania przez jerozolimskiego katechetę Listu do Rzymian św. Pawła. Wstępna kwerenda wykazała bowiem, że list Apostoła Narodów należy do często przytaczanych ksiąg biblijnych Nowego Testamentu. Cyryl bowiem powołuje się na niego ok. 40 razy, w zdecydowanej większości cytując poszczególne wypowiedzi św. Pawła.

Dokonując wstępnej analizy treści katechez, okazuje się, że odpowiednie teksty Listu do Rzymian Cyryl wykorzystuje jako biblijne uzasadnienie w czterech kręgach tematycznych. Są nimi: Osoby Boskie, które są przez katechetę omawiane osobno, oraz różne aspekty życia moralnego. Stąd też niniejsze przedłożenie zawiera naukę Cyryla w odniesieniu do wymienionych zagadnień katechetycznych z jednoczesnym ukazaniem Pawłowego nauczania.

1. Otwartość na Boga. Cyryl rozpoczął katechumenalny cykl spotkań od Katechezy wstęnej, w której nakreślił motywację uczestniczenia w naukach przedchrzcielnych, ukazując katechumenom w radosnych tonach wartości duchowe, jakie zapewnia przyjęty chrzest. W powitaniu uczestników biskup otwiera ich na królestwo niebieskie, gdzie panuje Bóg wszechmogący, przemawiając tymi słowy:

${ }^{*}$ Ks. prof. dr hab. Norbert Widok - kierownik Katedry Historii Kościoła i Patrologii na Wydziale Teologicznym Uniwersytetu Opolskiego; e-mail: nwidok@uni.opole.pl. 
„Szlachetny wasz zamiar i nadzieja. Nie kłamał ten, który powiedział: «Miłującym Boga wszystko służy ku dobremu» (Rz 8, 28). Hojny jest Bóg w dobrodziejstwach, czeka jednak na waszą szczerą decyzję. Dlatego dodał Apostoł: «Tym, którzy według postanowienia należą do powołanych» (Rz 8, 28). Jeśli twój zamiar jest szczery, uczyni cię powołanym. Jeśli tu jednak będziesz ciałem, a nie sercem, nie wyniesiesz stąd żadnej korzyści”"

Wiodącą ideą tej wypowiedzi jest podkreślenie wolności postawy duchowej każdego uczestnika wobec Boga. Cyryl bowiem nie pragnie nikogo zniewalać do przyjęcia chrztu, ale pozostawia każdemu decyzję wolnego wyboru polegającej na „szczerej decyzji” - jak się wyraził. Podjęcie tej decyzji poprzedził pochwałą ich przybycia na katechezę, wskazując na szlachetny zamiar i pokładaną w nich nadzieję. Jednak każdy katechumen tę decyzję musi podjąć przed obliczem Boga, który jest hojny w dobrodziejstwach. Jeśli zatem uczestniczenie każdego w katechezach i potem przyjęcie chrztu jest szczere, wówczas Bóg uczyni go powołanym. Jak można zauważyć, owo powołanie zależy do szczerego otwarcia się na Boga, a więc od wolnej decyzji. W przeprowadzeniu tej zachęty do dokonania wolnego wyboru wspomaga Cyryla św. Paweł, gdyż przytoczył w niej dwa jego krótkie stwierdzenia pochodzące z Listu do Rzymian, umieszczone w tym samym wersecie. Wypowiedź Cyryla jest krótkim komentarzem owego wersetu, w którym św. Paweł przekonuje o ścisłej relacji, jaka zachodzi pomiędzy miłującymi Boga a powołanymi przez Niego. Zdaniem egzegetów, wyrażenie „według postanowienia” oznacza obdarowanie człowieka jakimś dobrem nadprzyrodzonym, niezależnie od jego czynów. W kontekście chrztu tym obdarowaniem jest nowe istnienie, co właśnie odnosi się do bycia powołanym² ${ }^{2}$. Biskup Jerozolimy, mając przed sobą dopiero kandydatów do chrztu, nie wprowadza już od samego początku swych nauk zawiłych kwestii teologicznych, ale zaczyna od prawdy ogólnej: relacji Boga do człowieka i człowieka do Boga. Należy ponadto dodać, że wymienione dwa odniesienia biblijne tej katechezy, które występują tu jako pierwsze, są zaczerpnięte właśnie z Listu do Rzymian.

Wobec powyższego założenia biskup Jerozolimy na różne sposoby ukazuje konieczność przybliżenia się do Boga. Punktem wyjścia jest Jego poznanie, do czego zachęca. W kontekście nauczania o wolnej woli w Katechezie 4 wypomina brak dobrej woli w celu poznawania Go, wykorzystując przestrogę św. Pawła:

„Pomnij też na słowa Pisma Świętego: «Bo nie uznali za rozsądne zdobyć prawdziwego poznania Boga» $(R z 1,28)$ i «To, co o Bogu poznać można, jest jawne wśród nich» $(\mathrm{Rz} 1,19)^{\prime \prime}$.

${ }^{1}$ Cyrillus Hierosolymitanus, Procatechesis 1, PG 33, 333A-336A, thum. W. Kania, w: Św. Cyryl Jerozolimski, Katechezy przedchrzcielne i mistagogiczne, BOK 14, Kraków 2000, 19.

${ }^{2}$ Por. R.S. Zdziarstek, Chrystianologia św. Pawta, t. 1: Aspekt ontologiczny, Kraków 1989, 220.

${ }^{3}$ Cyrillus Hierosolymitanus, Catechesis 4 19, PG 33, 480B, BOK 14, 68. 
Ta wypowiedź składa się z dwóch cytatów pochodzących z tego samego passusu Listu do Rzymian, gdzie św. Paweł porusza zagadnienia poznawalności Boga przez pogan. $Z$ dosyć długiej refleksji na ten temat Cyryl wybrał jedynie dwa stwierdzenia, ukazujące funkcjonowanie woli w człowieku. Poznawanie bowiem Boga jest zależne od istotnej cechy woli, jaką jest rozsądne działanie. Wola pogan wykazała się bowiem brakiem rozsądnego podejścia do poznania prawdziwego Boga, gdyż oni raczej zadowalali się wierzeniami, do których byli przywiązani. „Prawdziwe poznanie Boga” - jak się wyraził Cyryl, powtarzając za św. Pawłem - nie interesowało pogan. Te słowa Apostoł Narodów napisał w sytuacji, kiedy we wcześniejszych wersetach ganił ich deprawację człowieczeństwa, zwłaszcza perwersje seksualne. Od perwersji kultycznej łatwo bowiem przejść do perwersji moralnej ${ }^{4}$, a wówczas trudno o działania rozsądne. Tymczasem mogli poganie skorzystać z tego, co było im dostępne dla poznania Boga. Zarówno Apostoł Narodów, jak i biskup Jerozolimy, uznali, że wiedza na temat Boga należy do tego, co ,jest jawne”.

Punktem kulminacyjnym nauczania o Bogu jest Katecheza 6 , w której biskup omawia pierwszy artykuł symbolu: „Wierzę w jednego Boga”. W pierwszej części katechezy (1-11) w sposób przystępny objaśnia katechumenom wielkość Najwyższej Istoty, natomiast druga jej część (12-36) poświęca omówieniu różnych herezji, a więc wszelkich błędnych interpretacji, które szkodzą prawdziwej wierze ${ }^{5}$. W części pierwszej, obok własnych refleksji świadczących o wierze Cyryla, pojawia się wiele odniesień biblijnych, wśród których jeden raz został przytoczony werset z Listu do Rzymian. Biskup bowiem snuje następującą refleksję:

„Jeśli nasz rozum nie może pojąć tego, co Bóg zgotował, to czy pojmiemy rozumem Tego, który nam je zgotował? «O głębokości bogactw, mądrości i umiejętności Boga! Jak niezbadane są wyroki Jego i niepojęte drogi Jego!» (Rz 11, 33)"'.

Katecheta odwołuje się zatem do świata stworzonego, praw natury obecnych w tym świecie, zmuszając tym samym katechumenów do refleksji nad jego pięknem, niepojętą złożonością, wielością bytów martwych i żywych po to, by następnie skierować myśl na Stwórcę tego wszystkiego. W ten sposób biskup ukazał słuchaczom przepaść dzielącą człowieka od Boga, którego nie da się pojąć ludzkim rozumem. W celu uzupełnienia swej refleksji Cyryl dołączył pierwszy werset hymnu na cześć niedościgłej mądrości Boga. Ten Pawłowy okrzyk wynika z podziwu i wdzięczności kierowanej ku szczodrobliwej Opatrzności Bożej, która zapewnia pomoc Żydom i poganom w osiagnięciu

\footnotetext{
${ }^{4}$ Por. List do Rzymian, thum., wstęp i koment. H. Langkammer, Lublin 1999, 36.

${ }^{5}$ Szerokie studium dotyczące tego zagadnienia opracował N. Widok, Polemika antyheretycka w ,Catechesisch” Cyryla Jerozolimskiego, VoxP 37 (2017) t. 68, 423-442 (spec. s. 427-430, odnoszące się do omawianego passusu).

${ }^{6}$ Cyrillus Hierosolymitanus, Catechesis 6, 9, PG 33, 553A, BOK 14, 93.
} 
zbawienia. Podkreślona tu została rola Izraela w Bożym planie zbawienia7 Ważne zatem było nawiązanie do tego wersetu, aby odwołać się do świadomości pokoleniowej uczestników zapisanych do katechumenatu, pochodzących z rodzin pogańskich i żydowskich z Jerozolimy i jej okolic.

2. Wierność Jezusowi Chrystusowi. Każda katecheza prowadzona przez Cyryla była poprzedzona odczytaniem fragmentu Pisma Świętego. List do Rzymian został również przez niego dowartościowany, i to dwukrotnie: raz w serii katechez kierowanych do katechumenów, drugi raz - w serii katechez mistagogicznych. W pierwszym przypadku fragment tego listu odczytano na początku Katechezy 3, w której biskup objaśnia istotę chrztu (Rz 6, 3-4)8. Dzięki lekturze tego tekstu Cyryl przybliżył słuchaczom rolę Jezusa Chrystusa względem każdego, kto przyjmuje chrzest. Należy założyć, że ta prawda mogła wydawać się trudna w przyjęciu jej przez początkujących adeptów chrztu. Stąd też w toku katechezy pojawia się dłuższy komentarz biskupa wyjaśniający istotę chrztu, czyli zanurzenia się w wodzie:

„Wskutek grzechu wchodzisz umarły, ale wychodzisz zbudzony do życia w sprawiedliwości. Jeśliś bowiem wrósł w podobieństwo śmierci Zbawiciela, będziesz też godny Jego zmartwychwstania. Jak Jezus wziął na siebie grzechy świata i umarł, aby zniszczyć grzech i wskrzesić cię w sprawiedliwości, tak i ty, wszedłszy do wody i jakby pogrzebany w wodzie jak On w skalnym grobie, znów zostaniesz wskrzeszony, aby «wieść nowe życie» (Rz 6, 4)"”.

W tej wypowiedzi zostały wymienione i pokrótce wyjaśnione prawdy składające się na akt chrztu, wcześniej podane już w odczytanym fragmencie Listu do Rzymian na rozpoczęcie katechezy ${ }^{10}$. Cyryl nie podaje szczegółowej wykładni tych prawd, lecz je jedynie zapowiada, by do nich powrócić i szerzej omówić w kolejnych katechezach. Punktem kulminacyjnym powyższego wyjaśnienia jest krótka uwaga dosłownie zapożyczona od św. Pawła, będąca zachętą wejścia „W nowe życie”, co stanie się w przypadku katechumenów z chwilą przyjęcia przez nich chrztu. Celem zatem przekazywania przez biskupa kerygmatu słuchaczom i doprowadzenia ich do przyjęcia chrztu jest inne życie, tzn. ujęte w kategoriach duchowości ewangelicznej. Sprawcą tego typu możliwości wstąpienia na inny poziom wartościowania i nowego życia jest Jezus Chrystus.

Katechumeni obszernie dowiedzieli się o Nim przez wysłuchanie Katechezy 10, która traktuje o kolejnym artykule symbolu wiary, zatytułowanym

${ }^{7}$ Por. Katolicki komentarz biblijny, red. W. Chrostowski, Warszawa 2001, 1310.

${ }^{8}$ Tekst brzmi następująco: „Czyż nie wiadomo wam, że my wszyscy, którzyśmy otrzymali chrzest zanurzający w Chrystusa Jezusa, zostaliśmy zanurzeni w Jego śmierć? Zatem przez chrzest zanurzający nas w śmierć zostaliśmy razem z Nim pogrzebani po to, abyśmy i my wkroczyli w nowe życie - jak Chrystus powstał z martwych dzięki chwale Ojca".

${ }^{9}$ Cyrillus Hierosolymitanus, Catechesis 3, 12, PG 33, 444A, BOK 14, 55.

${ }^{10}$ Szerokie studium poszczególnych aspektów zawartych w Rz 6 opublikował H. Schlier, Die Taufe nach dem 6. Kapitel des Römerbriefen (Die Zeit der Kirche), Freiburg 1966. 
„I w jednego Pana Jezusa Chrystusa”. Obok bardzo licznych odniesień do tekstów biblijnych, tylko jeden raz Cyryl skorzystał z myśli zaczerpniętej z Listu do Rzymian. Omawiając bowiem określenie „kamień węgielny”, biskup naucza:

„Zwie się Chrystus «kamieniem», nie martwym, ludzkimi rękami wyciosanym, lecz «kamieniem węgielnym». Kto na nim oprze nadzieję, nie będzie musiał się wstydzić (por. Rz 9, 33)"11.

Obraz kamienia zastosowany w tym pouczeniu dla mieszkańców Jerozolimy i jej okolic był właściwą ilustracją prawdy, którą Cyryl chciał przekazać. Otóż wielka ilość kamieni, które znajdowały się w Palestynie, były nieustannie pod ręką i w myślach Izraelitów. W symbolice tamtejszych ludów był oznaką siły, trwałości i mocy. Dlatego Biblia pod różnymi postaciami przywołuje obrazy kamieni, aby odnieść je do Mesjasza ${ }^{12}$. Wśród wielu odniesień semantycznych Jezus Chrystus został nazwany „kamieniem węgielnym”, a więc oznaczającym silne podłoże do budowania solidnej konstrukcji, w tym przypadku duchowej, bo nie był On „martwym” kamieniem, jak zaznacza biskup. Dlatego Cyryl w następstwie takiego założenia mógł dopowiedzieć parafrazę wersetu z listu św. Pawła: ,a kto wierzy w niego, nie będzie zawstydzony”, co odnosi się do Żydów, którzy bardziej zaufali swoim uczynkom poprzez wypełnienie prawa, pomijając wiarę ${ }^{13}$. Autor katechezy dokonał jednak pewnej modyfikacji, wprowadzając słowo „nadzieja” w miejsce wiary. Zatem katechumeni usłyszeli zapewnienie, że Jezus Chrystus to solidny fundament, na którym bez zawstydzenia można pokładać nadzieję.

Prawdę o Wcieleniu Jezusa Chrystusa Cyryl wyłożył w Katechezie 12. Stąd też jej treść zawiera dosyć często pojawiające się rozważania dotyczące ciała. Jedna z refleksji przedstawia relację pomiędzy ciałem a Szatanem:

„Bóg prawdziwie stał się człowiekiem, by położyć kres kłamstwu. Szatan w walce przeciw nam jako bronią posłużył się ciałem, stąd Paweł mówi: «Widzę inne prawo w członkach moich, walczące z prawem mego rozumu i oddającego mnie w niewolę» $(\mathrm{Rz} 7,23)$. Tą samą bronią, jaką zwalczał nas szatan, zostaliśmy wybawieni" ${ }^{14}$.

Jerozolimski katecheta skupił się na wyjaśnieniu jednego z celów przyjęcia przez Chrystusa natury cielesnej. Posiadanie bowiem przez Niego ciała zestawił z aktywnością Szatana, który atakuje człowieka głównie za pośrednictwem ciała. Bóg, pragnąc wyzwolić go z niewoli cielesnej, również posłużył się ciałem, przyjmując go jako drugą naturę obok Boskiej. Zatem zarówno

\footnotetext{
${ }^{11}$ Cyrillus Hierosolymitanus, Catechesis 10, 3, PG 33, 664B, BOK 14, 134.

${ }^{12}$ Por. P. Lamarche, Kamień, w: Stownik teologii biblijnej, red. X. Leon-Dufour, thum. K. Romaniuk, Poznań - Warszawa 1982, 360.

${ }^{13}$ Por. J. Stępień, Eklezjologia św. Pawła, Poznań - Warszawa - Lublin 1972, 142-143.

${ }^{14}$ Cyrillus Hierosolymitanus, Catechesis 12, 15, PG 33, 741B, BOK 14, 169-170.
} 
Szatan, jak i Chrystus, swe zamiary wobec człowieka realizują zatem poprzez ciało: Szatan zwalcza człowieka, Chrystus go wybawia. Dla zilustrowania oddziaływania na człowieka mocy szatańskiej Cyryl przywołuje myśl św. Pawła, który zdaje sobie sprawę z obecności w jego członkach praw obcych prawom rozumu i prowadzących go do niewoli. To ,inne prawo” oznacza zamieszkały w człowieku grzech, który przeciwstawia się ,prawu rozumu” w ten sposób, że zniewala człowieka, aby Prawo Boże nie było już wolne, by go przestrzegać $^{15}$. Według biskupa pojawia się w tych relacjach kłamstwo, któremu należy położyć kres, a to może uczynić tylko Wcielony Jezus Chrystus.

Ideę przyjęcia przez Chrystusa ciała Cyryl rozwija, dopowiadając kolejną myśl dotyczącą zbawienia człowieka. Jego słowa są następujące:

„Pan przyjął coś naszego, aby zbawić ludzi. Przyjął coś naszego, by temu, co ma braki, dać tym większą łaskę, aby grzeszna ludzkość miała uczestnictwo w Bogu. «Gdzie wzmógł się grzech, tam tym obficiej wylała się łaska» $(\mathrm{Rz} 5,20){ }^{\text {”16. }}$.

W tej wypowiedzi Cyryl wyjaśnia następny cel Wcielenia Chrystusa: skoro bowiem Pan ,przyjął coś naszego”, to uczynił to po to, aby „ludzkość miała uczestnictwo w Bogu". Ma tu miejsce idea przebóstwienia człowieka, czyli przekazanie mu czegoś boskiego. Dlatego w tym kontekście katecheta dodał słowa św. Pawła mówiące o wylaniu się łaski z powodu grzechu zaistniałego w ciele. Poprzez ten akt nastapił koniec panowania śmiercionośnego grzechu i jednocześnie rozpoczął się czas obecności łaski, będącej darem sprawiedliwości Bożej, który dzięki Jezusowi Chrystusowi stał się dostępny dla wiernych ${ }^{17}$.

Szczytem przyjęcia ludzkiego ciała przez Jezusa Chrystusa jest akt końcowy Jego życia w ciele, czyli ukrzyżowanie. Ten trudny do zaakceptowania moment, mający w rzeczywistości drastyczny przebieg, Cyryl przedstawia w swobodnie brzmiącej narracji:

„Wyciagnął swe ludzkie ręce Ten, który swymi duchowymi rękami umocnił niebiosa. Przebite one zostały gwoździami. Przez przybicie do krzyża i śmierć ludzkiej natury, obciążonej ludzkimi grzechami, równocześnie i grzech umark, a my w sprawiedliwości powstaliśmy z martwych"18.

Biskup uwielbia Chrystusa z powodu Jego zaangażowania w dziele zbawienia człowieka, ponieważ najpierw swymi rękami „umocnił niebiosa”, czyli brał udział w stworzeniu wszechświata, a potem te same ręce ,przebite zostały gwoździami”. Cyryl uświadamia słuchaczy, że ten akt był konieczny, aby miało miejsce unicestwienie grzechu, a to mogło się dokonać tylko poprzez śmierć ludzkiej natury Jezusa Chrystusa. Konsekwencją tego było powstanie

\footnotetext{
${ }^{15}$ Por. Katolicki komentarz biblijny, s. 1293.

${ }^{16}$ Cyrillus Hierosolymitanus, Catechesis 12, 15, PG 33, 741BC, BOK 14, 170.

${ }^{17}$ Por. List do Rzymian, tłum., wstęp i koment. Langkammer, s. 78.

${ }^{18}$ Cyrillus Hierosolymitanus, Catechesis 13, 28, PG 33, 895B, BOK 14, 199-200.
} 
z martwych. Tę myśl o owocach ukrzyżowania jerozolimski pasterz zaczerpnął z Listu do Rzymian, parafrazując zapis św. Pawła ${ }^{19}$.

Niezwykle interesującą interpretację Cyryl przekazał katechumenom, relacjonując treść dialogu, jaki odbył się na krzyżu pomiędzy Jezusem Chrystusem a łotrem. Komentarz biskupa do tej sceny jest dosyć długi, a kończy się taką puentą: „On boi się Pana! O wielka i niewypowiedziana łaska! Nie wszedł jeszcze do raju wierny Abraham, a łotr już wchodzi. Jeszcze nie weszli Mojżesz i prorocy, a grzeszny łotr wchodzi" ${ }^{20}$. Bezpośrednią kontynuacją tych słów stała się wypowiedź św. Pawła, wyżej już cytowana i omawiana, a mianowicie: „Gdzie wzmógł się grzech, tam tym obficiej wylała się Łaska” (Rz $5,20)^{21}$. Biskup ukazuje słuchaczom prawdę o dobrodziejstwie wysłużonym przez Chrystusa na krzyżu, którego jako pierwszy doznał łotr. Dla zilustrowania głębi przekazu tego wydarzenia katecheta powtórnie skorzystał z wypowiedzi św. Pawła. W życiu bowiem łotra dominował grzech, ale z powodu jego skruchy już na krzyżu wylała się na niego łaska zbawienia.

Tematem Katechezy 14 jest nauka o zmartwychwstaniu Jezusa Chrystusa i Jego wniebowstapieniu. Cyryl dał szeroki popis swoich umiejętności katechetycznych, ponieważ na różne sposoby pragnął wyjaśnić słuchaczom te zasadnicze tajemnice wiary. $Z$ pomocą $w$ tych wyjaśnieniach przychodzi mu św. Paweł, gdyż kilkanaście razy odwołuje się do jego listów, z czego aż dziesięciokrotnie w passusie 21. Najpierw trzy razy przywołuje krótkie stwierdzenia z Listu do Rzymian potwierdzające prawdziwość Jego zmartwychwstania, by następnie skorzystać z innych jego listów. W tym passusie Cyryl polemizuje z manichejczykami, którzy nie uznawali zmartwychwstania. Dlatego katecheta wychodzi w swym dowodzeniu od autorytetu św. Pawła, który oznajmił w tym liście, że Chrystus wedle ciała pochodzi z rodu Dawida (por. $\mathrm{Rz} 1,3$ ), a przez powstanie z martwych jest pełnym mocy Synem Bożym (por. Rz 1,4), by potem doradzać w kwestii otchłani i wyprowadzenia Chrystusa z martwych (por. Rz 10, 6) ${ }^{22}$. W tradycji biblijno-patrystycznej tekst Rz 1, 3-4 uchodzi za podstawę do rozważań chrystologicznych. Zawiera bowiem zwroty starsze od Ewangelii, które powstały w środowisku chrześcijan pochodzenia żydowskiego, będących pod wpływem prądów hellenistycznych. Ponadto tekst ten zwraca uwagę na Mesjasza jako Syna Dawida oraz synostwo Boże Jezusa ${ }^{23}$.

${ }^{19}$ Dosłowny tekst brzmi następująco: „To wiedzcie, że dla zniszczenia grzesznego ciała dawny nasz człowiek został razem z Nim ukrzyżowany po to, byśmy już więcej nie byli we niewoli grzechu" (Rz 6, 6).

${ }^{20}$ Cyrillus Hierosolymitanus, Catechesis 13, 31, PG 33, 809B, BOK 14, 201.

${ }^{21}$ Ten werset pochodzi z perykopy Rz 5, 12-21, która stanowi zasadniczy tekst dla argumentacji całego Listu do Rzymian w odniesieniu do istoty grzechu pierwszego człowieka, zob. K. Romaniuk, Soteriologia św. Pawła, Warszawa 1983, 160-164.

${ }^{22}$ Por. Cyrillus Hierosolymitanus, Catechesis 14, 21, PG 33, 851A, BOK 14, 223.

${ }^{23}$ Więcej szczegółów interpretacyjnych wynikających z tego tekstu podaje H. Langkammer, Hymny chrystologiczne Nowego Testamentu. Najstarszy obraz Chrystusa, Katowice 1976, 67-79. 
W dalszej części tej katechezy biskup Jerozolimy jeszcze raz powołuje się na List do Rzymian, przytaczając te same co wyżej stwierdzenia: „Apostoł Paweł mówi w liście do Rzymian: Chrystus, który umarł, więcej, zmartwychwstał, który jest po prawicy Boga (Rz 8, 34)"24. To stwierdzenie, wypowiedziane przy końcu katechezy, stanowi lapidarne podsumowanie pouczeń w niej zawartych. Sens tych słów jest niezwykle wzniosły i ma umacniać na duchu przyszłych ochrzczonych. Syn Boży jest bowiem orędownikiem u Boga, ponieważ umarł, odkupił człowieka i wstawia się za nim po Jego prawicy, co oznacza, że Jezus jest najbliżej Boga i potrafi działać bardzo skutecznie ${ }^{25}$.

Kolejną prawdę wiary biskup Jerozolimy omówił w Katechezie 15. Poruszył w niej kwestie związane z eschatologią, to znaczy z osądzeniem żywych i umarłych. Bardzo jednoznacznie wyraził się o Jezusie Chrystusie:

„Na wieki bowiem jest Król Sędzią żywych i umarłych, bo umarł za żywych i umarłych. Paweł mówi: «Dlatego Chrystus umarł i zmartwychwstał, aby panował nad umarłymi i nad żywymi» (Rz 14, 9)"26.

W tym stwierdzeniu katecheta podkreślił ważną ideę wynikającą z Jego śmierci i zmartwychwstania: stał się poprzez te fakty sędzią wobec żywych i umarłych. Jego władza sądzenia jest uniwersalna, ponieważ odnosi się do ludzi żyjących, a także tych, którzy umarli. Po obwieszczeniu tej prawdy wiary jerozolimski katecheta swój przekaz poparł wypowiedzią św. Pawła, który w tych samych słowach opisał w swym liście tę myśl. Ponadto z Listu do Rzymian wybrzmiewa dodatkowa myśl, w której św. Paweł podkreślił cel śmierci i zmartwychwstania Chrystusa, a jest nim właśnie władza sądzenia ${ }^{27}$. Cyryl nazwał Go Królem „na wieki”, stąd jego władza rozciaga się na czasy przeszłe, teraźniejsze oraz przyszłe. W ten sposób została zapowiedziana przez niego idea wiecznego królestwa, którą objaśnia w następnym passusie.

W odniesieniu do Osoby Jezusa Chrystusa pojawia się bowiem wypowiedź interpretująca Jego wieczne królestwo w polemice z tzw. przeciwnikami i powiązana z nim kwestia śmierci. Cyryl, chcąc uwiarygodnić swe nauczanie, wprost przywołuje św. Pawła:

„Ponieważ na podstawie słów «aż wszystkich nieprzyjaciół położy pod swoje stopy» odważyli się mówić o końcu Chrystusa, ograniczyć Jego wieczne królestwo i nieprzemijającą moc sprowadzić do swej nauki, przeczytajmy podobne miejsce u Apostoła: «Śmierć panowała od Adama aż do Mojżesza» (Rz $5,14)$. Czyż tylko do tego czasu umierali ludzie i po Mojżeszu nikt już nie umarł? Czyż po prawie nie było śmierci ludzi?’’28

${ }^{24}$ Cyrillus Hierosolymitanus, Catechesis 14, 29, PG 33, 861C, BOK 14, 227.

${ }^{25}$ Por. List do Rzymian, tłum., wstęp i koment. Langkammer, s. 116.

${ }^{26}$ Cyrillus Hierosolymitanus, Catechesis 15, 26, PG 33, 909A, BOK 14, 249.

${ }^{27} \mathrm{Na}$ temat sądu w teologii św. Pawła zob.: A. Jankowski, Eschatologia biblijna Nowego Testamentu, Kraków 1987, 95-98.

${ }^{28}$ Cyrillus Hierosolymitanus, Catechesis 15, 31, PG 33, 913A, BOK 14, 251. 
Ta wypowiedź miała na celu wyjaśnienie słuchaczom istotnej kwestii w ich wierze w Jezusa Chrystusa, a mianowicie Jego wieczne królowanie. Tę prawdę przedstawił w kontekście błędnego nauczania heretyków, na obecność których Cyryl ponownie kandydatów do chrztu uwrażliwiał. Błędnowiercy uczepili się bowiem słówka „aż” w odniesieniu do czasu królowania Chrystusa, a właściwie Jego wiecznego królowania. Pomocna okazała się wypowiedź św. Pawła, który zwrócił uwagę na rzeczywistość śmierci po grzechu Adama. Ta wyjęta z kontekstu wypowiedź może sugerować zróżnicowanie w podejściu do grzechu w czasach przed i po Mojżeszu, czyli przed i po momencie zaistnienia Prawa. To czasowe rozróżnienie w Liście do Rzymian miało na celu podkreślenie funkcji Tory w kontekście powszechności grzechu. Ludzie żyjący przed powstaniem Prawa wprawdzie nie popełnili przestępstwa wykroczenia przeciw Prawu, ponieważ go jeszcze nie było, to jednak oni także ściągnęli na siebie śmierć, gdyż w ogóle popełniali różnego rodzaju przestępstwa. A zatem o śmierci nie decyduje przestępstwo wobec Prawa, ale śmiercionośna moc grzechu, który poprzez nieposłuszeństwo Adama pojawił się w całym rodzaju ludzkim ${ }^{29}$. Znaczenie wyjaśnienia tej kwestii było dla Cyryla niezwykle istotne, gdyż pośród słuchaczy byli nie tylko adepci pochodzący z rodzin pogańskich, ale także z judaizmu, gdzie nauczanie o roli Prawa było ważne.

Natomiast Katecheza 20 należy do nauk mistagogicznych, a więc tych, których wysłuchiwano po przyjęciu chrztu. Ta katecheza staje się kluczową do pełniejszego zrozumienia istoty i znaczenia przyjętego sakramentu, ponieważ wprost dotyczy chrztu. Przygotowaniem do uczestniczenia w tej nauce katechetycznej było najpierw wysłuchanie dłuższego fragmentu z Listu do Rzymian (Rz 6, 3-14). Ta biblijna perykopa zawiera szerokie wyjaśnienie znaczenia chrztu, który przede wszystkim zadaje śmierć grzechowi. Fragmenty tej biblijnej perykopy zostały podczas tej nauki wykorzystane w celu objaśnienia bardziej szczegółowych kwestii związanych z chrztem. Biskup zwraca najpierw uwagę na ścisłe powiązanie ochrzczonego z Chrystusem, co ujął w słowach:

„Wiemy dobrze, że chrzest nie tylko oczyszcza z grzechów i daje dar Ducha

Świętego, lecz też jest obrazem cierpień Chrystusa. Dlatego woła Paweł: «Czyż nie wiecie, że my wszyscy ochrzczeni na Chrystusa Jezusa, na śmierć Jego ochrzczeni jesteśmy? Jesteśmy więc wespół z Nim pogrzebani przez chrzest» (Rz 6, 3-4)"30.

Św. Paweł uświadamia Rzymian, jakie skutki w życie człowieka wnosi przyjęty chrzest. Przypomina, że przede wszystkim oczyszcza z grzechów oraz obdarza darami Ducha Świętego. Te treści nie zostały przez Cyryla szerzej skomentowane, ponieważ należą do podstawowych wiadomości z wie-

\footnotetext{
${ }^{29}$ Por. List do Rzymian, tłum., wstęp i koment. Langkammer, s. 73-74.

${ }^{30}$ Cyrillus Hierosolymitanus, Catechesis 20, 6, PG 33, 1081B, BOK 14, 327.
} 
dzy religijnej kierowanej do katechumena ${ }^{31}$. Nieco więcej natomiast uwagi katecheta poświęcił kolejnej myśli, wymagającej głębszej refleksji teologicznej. Streścił ją stwierdzeniem, iż chrzest ,jest obrazem cierpień Chrystusa”. Ideę zawartą w tym określeniu chrztu wyjaśnił przytoczeniem wypowiedzi Pawłowej, która ukazuje, na czym polega ścisły związek pomiędzy śmiercią Chrystusa i chrztem. Otóż śmierć Chrystusa nie była celem Jego dzieła zbawczego, lecz jedynie środkiem do celu, którym jest zwycięstwo nad grzechem i śmiercią poprzez zmartwychwstanie. Dlatego umieranie dla grzechu mające miejsce w sakramencie chrztu przynosi nowe życie w Bogu. Następstwem tego ma być nowy styl życia chrześcijańskiego ${ }^{32}$.

W kolejnym nawiązaniu do listu św. Pawła biskup Jerozolimy porusza następną kwestię wynikającą z przyjęcia chrztu, gdyż konsekwencją zanurzenia w śmierci Chrystusa staje się także udział w Jego zmartwychwstaniu. Tę zbawczą ideę Cyryl wyjaśnił w następujących słowach:

„Abyśmy wiedzieli, że wszystko, co wycierpiał Chrystus prawdziwie, a nie pozornie wycierpiał dla nas i dla naszego zbawienia i uczynił nas uczestnikami swych cierpień, mówi Paweł: «Jeśli zostaliśmy z Nim zrośnięci w jedno przez podobieństwo ze śmiercią Jego, będziemy też zrośnięci z Nim w jedno przez podobieństwo w zmartwychwstaniu» $(\mathrm{Rz} 6,5)^{{ }^{\prime 3} 3}$.

Zanim Cyryl oznajmił słuchaczom, na czym polegają owoce śmierci i zmartwychwstania Chrystusa, odniósł się do błędnego pojmowania charakteru Jego śmierci. Otóż w świadomości niektórych chrześcijan tkwił błąd wadliwego rozumienia natury ludzkiej. Uważali oni bowiem, że ciało Jezusa Chrystusa po wcieleniu miało wygląd pozorny, a w konsekwencji także Jego śmierć musiała mieć charakter pozorny ${ }^{34}$. Należy dodać, iż takie pojmowanie ludzkiej natury Chrystusa pojawiło się już na początku II w., które zwalczał m.in. Ignacy Antiocheński ${ }^{35}$. Można zatem suponować, że również w połowie IV w. istnieli wyznawcy takiego błędnego poglądu, skoro Cyryl wprost potępia tego typu rozumowanie. W swojej katechetycznej mowie podkreśla bowiem, że Chrystus cierpiał ,prawdziwie, a nie pozornie”. Jest to niezwykle istotne stwierdzenie w nauczaniu chrystologicznym pierwszych wieków chrześcijańskich $^{36}$.

${ }^{31}$ Wiele interesujących myśli w kontekście tego sformułowania podaje K. Mcdonnell - G.T. Montague, Inicjacja chrześcijańska a chrzest w Duchu Świętym, thum. M. Górnicki - W. Kustra, Kraków 1997, 270-272.

${ }^{32}$ Por. List do Rzymian, tłum., wstęp i koment. Langkammer, s. 80.

${ }^{33}$ Cyrillus Hierosolymitanus, Catechesis 20, 7, PG 33, 1084A, BOK 14, 327.

${ }^{34}$ Całe studium tej problematyce poświęcił G. Jaśkiewicz, Doketyzm jako wyraz relatywizmu w teologii, Ząbki 2011 (zwłaszcza rozdział IV: „Argumenty biblijno-patrystyczne w polemice antydoketystycznej”, s. 148-240).

${ }^{35}$ Por. tenże, Polemika antydoketystyczna u św. Ignacego z Antiochii, „Studia Ełckie” 13 (2011) 401-408.

${ }^{36}$ Ignacy Antiocheński w zwalczaniu błędu doketów stosował w swoich listach słowo „na- 
Ostatnie nawiązanie do treści Listu do Rzymian w kontekście relacji względem Jezusa Chrystusa biskup jerozolimski umieścił w Katechezie 21, będącej kolejną nauką mistagogiczną. Tę katechezę poświęcił bierzmowaniu, rozpoczynając ją słowami:

„W Chrystusie ochrzczeni i w Chrystusie przyobleczeni staliście się podobni do Syna Bożego (por. Rz 8, 29)"'37.

To stwierdzenie składa się z kilku informacji kerygmatycznych nawiązujących do poprzednich katechez i będących jednocześnie powtórzeniem usłyszanych przedtem treści. Cyryl bowiem przypomina, że słuchacze zostali ochrzczeni w Chrystusie, a konsekwencją tego jest fakt przyobleczenia się w Chrystusa. Następstwem tego z kolei ochrzczeni stają się do Niego podobni. To ostatnie stwierdzenie stanowi parafrazę wypowiedzi Pawłowej z jego listu. Okazuje się, że idea mówiąca o podobieństwie do Chrystusa niesie z sobą głębokie treści teologiczne. W Liście do Rzymian św. Paweł wyraził ją następująco: „Wszystkich, których od wieków poznał, tych także przeznaczył na to, aby się stali podobni do obrazu Jego Syna, aby On był pierworodnym pośród wielu braci" (Rz 8, 29). Porównując tekst biblijny z parafrazą biskupa Jerozolimy, łatwo zauważyć wybiórczość dokonaną przez Cyryla. Wybrał on bowiem jedną ideę, widocznie postrzeganą przez niego za najważniejszą, aby skupić uwagę słuchaczy na jednym szczególe, bez wnikania w pozostałe myśli tego cytatu. Wśród egzegetów przeważa opinia, że to stwierdzenie jest swego rodzaju komentarzem do słów zapisanych w Księdze Rodzaju: „Uczyńmy człowieka na Nasz obraz, podobnego Nam” $(\operatorname{Rdz} 1,26)$. Mimo chrystocentrycznego ujęcia podobieństwa z Bogiem wyrażonego przez św. Pawła, nie znika pierwotne jego znaczenie. Pojawia się także zbawcze jego ukierunkowanie, gdyż nastąpiło ubóstwienie człowieczeństwa poprzez pojawienie się Chrystusa w świecie, a jednocześnie w tym ubóstwieniu uczestniczy odkupiona ludzkość. Należy ponadto podkreślić, że owo podobieństwo nie odnosi się jedynie do wybranych, ale do wszystkich, ponieważ Bóg wszystkich powołał do zbawienia ${ }^{38}$. Być zatem podobnym do Syna Bożego to stać się Jego bratem.

3. Akceptacja Ducha Świętego. Pouczenia o Duchu Świętym Cyryl przekazał w dwóch katechezach, w których także pojawiają się odniesienia do Listu do Rzymian. Pierwsza z nich, Katecheza 16, zawiera kilka passusów, w których zostały zebrane błędy heretyckie dotyczące Ducha Świętego (4-10). Te rozważania miały ostrzec katechumenów, by nie popaść w podobne uzależnienia. Obok błędnego postrzegania tej Boskiej Osoby katecheta przekazuje

prawdę", podkreślające wagę i istotę rzeczy; por. N. Widok, Wiara - miłość - nadzieja. Studium w oparciu o listy Ignacego z Antiochii, Opole 2011, 58-59.

${ }^{37}$ Cyrillus Hierosolymitanus, Catechesis 21, 1, PG 33, 1088A, BOK 14, 331.

${ }^{38}$ Por. List do Rzymian, thum., wstęp i koment. Langkammer, s. 112-113. 
słuchaczom wiele pozytywnych o Niej wiadomości. Zwraca uwagę na szczególną pomoc Ducha podczas modlitwy, kierując do słuchaczy słowa:

„Duch Święty zwie się Pocieszycielem, bo pociesza, wlewa otuchę, usuwa słabość. «Nie wiemy, o co się modlić jak należy, lecz sam Duch wstawia się za nami w niewysłowionych westchnieniach» $(\mathrm{Rz} 8,26)^{\prime \prime 39}$.

Biskup zatem uwagę katechumenów kieruje na bardzo istotną funkcję Ducha Świętego, oznajmiając, że jest On Pocieszycielem. Człowiek z natury swej lubi być pocieszany, stąd tkwi w nim inklinacja na doznawanie pocieszeń, zwłaszcza gdy jego dusza przeżywa chwile negatywne. Cyryl dodaje, że oprócz pocieszenia Duch Święty „wlewa otuchę, usuwa słabość”, a więc przyczynia się do duchowej przemiany i pozytywnego nastawienia. Te duchowe właściwości są bardzo ważne w czasie modlitwy, gdyż z pomocą przychodzi Duch Święty ${ }^{40}$ - na co najpierw w swoim liście zwrócił uwagę św. Paweł, a Cyryl powtórzył jego myśl.

Inną okolicznością życiową, w której Duch Święty przychodzi z pomoca, są chwile trudne, graniczące $\mathrm{z}$ cierpieniem. Takie sytuacje Cyryl komentuje w ten sposób:

„Niejeden dla Chrystusa doznał zniewag i wzgardy, niejednemu groziło męczeństwo i katusze - ogień, miecz, dzikie zwierzęta, przepaść. Ale Duch Święty mówił do niego: «Oczekuj Pana» $(\mathrm{Rz} 8,19)$ - człowiecze! Małe jest to, co cierpisz, wielkie to, co ci będzie dane. Krótki czas cierpienia przyniesie ci wieczne życie z aniołami" ${ }^{\prime 1}$.

Cyryl przedstawił inne chwile w życiu człowieka, które należy zakwalifikować do negatywnych, a są nimi sytuacje zagrożenia życia w postaci męczeństwa doznanego przez różnego rodzaje katusze. W tych trudnych sytuacjach ulgę przynosi Duch Święty słowami „oczekuj Pana”, które Cyryl przejął od św. Pawła ${ }^{42}$. W tym pouczeniu dominuje jednak idea o przyszłym życiu, w którym nie będzie już żadnych form cierpienia, ale radość dzielona wraz $\mathrm{z}$ aniołami. Słowa Cyryla kierowane do katechumenów mają wymiar eschatologiczny, przygotowujący ich na osiągnięcie takiego stanu nawet poprzez cierpienia.

Natomiast Katecheza 17 jest kontynuacją nauki o Duchu Świętym, w której Cyryl o wiele częściej powołuje się na teksty biblijne. List do Rzymian posłużył mu, aby objaśnić katechumenom istnienie różnych nazw odnoszących się do Ducha Swiętego. W początkowej części katechezy pojawia się więc nagromadzenie cytatów biblijnych zawierających określenia tej Boskiej Osoby. Katecheta zatem m.in. tak naucza:

\footnotetext{
${ }^{39}$ Cyrillus Hierosolymitanus, Catechesis 16, 20, PG 33, 948A, BOK 14, 267.

${ }^{40}$ Por. R. Pesch, Römerbrief, Würzburg 1983, 73.

${ }^{41}$ Cyrillus Hierosolymitanus, Catechesis 16, 20, PG 33, 948A, BOK 14, 267.

${ }^{42}$ Odniesienia do nadziei skierowanej ku życiu wiecznemu w teologii św. Pawła podaje K. Romaniuk, Soteriologia św. Pawła, s. 295-296.
} 
„Zwie się również «Duchem Bożym», [...]. I na innym miejscu: «Ci, których prowadzi Duch Boży, są dziećmi Bożymi» $(\mathrm{Rz} 8,14){ }^{\prime 43}$.

Powyższa myśl św. Pawła została wyjęta z tego fragmentu jego listu, w którym Duch Święty przedstawiony jest w swoich różnorakich zadaniach. Cyryl pośród nich zwrócił uwagę na tzw. afiliację, czyli usynowienie chrześcijan, o czym daje świadectwo Duch Święty ${ }^{44}$. Zauważa się, że powyższy cytat z listu Apostoła Narodów jest pierwszym stwierdzeniem wprowadzającym w tym liście temat synostwa, za pomocą którego św. Paweł opisuje nowy status chrześcijanina względem Boga ${ }^{45}$. W tym kontekście nie należy się dziwić, że jerozolimski biskup dostrzegł wagę tej idei i podkreślił ją w swej katechetycznej mowie.

W dalszej części tego passusu Cyryl ponownie wymienia ten sam tytuł odnoszący się do Ducha Swiętego i dodaje kolejne refleksje z tego wynikające:

„Zwie się «Duchem Bożym i Chrystusowym», jak pisze Paweł: «Nie jesteście w ciele, lecz w duchu, jeśli tylko Duch Boży w was mieszka. Jeśli zaś kto nie ma Ducha Chrystusowego, ten nie jest Jego» (Rz 8, 9)"46.

Cyryl, opierając się na pouczeniu św. Pawła, przekazuje katechumenom ważną prawdę dotyczącą działania Ducha Świętego w życiu tych, którzy Go przyjęli. Zamieszkanie Ducha Bożego w ciele nie oznacza jednak ingerencji w naturę ludzką, gdyż dalej pozostaje naturą śmiertelną. Wprawdzie Duch Święty sprawia przemianę w duszy człowieka, jednak bez naruszenia jego wolności, czyli bez uszczuplania wolnej woli. Działalnie Ducha Bożego posiada moc uzdrawiającą i wzmacniającą wolę człowieka. Również Duch Święty tę moc okazał, dokonując na Chrystusie aktu wskrzeszenia ${ }^{47}$. Ze względu na obecność Ducha Świętego w człowieku, pozostaje on w łączności z Chrystusem i wówczas duch ludzki żyje ${ }^{48}$. Ta bogata teologia Pawłowego stwierdzenia stała się podstawą dla Cyryla, by nazwać Ducha Świętego „Duchem Bożym i Chrystusowym".

Jerozolimski katecheta przytoczył w swej mowie inne jeszcze nazwy Ducha Świętego pochodzące z Listu do Rzymian. Powiedział do słuchaczy: „Zwie się On «Duchem uświęcenia», jako napisano: «Według Ducha uświęcenia» $(\mathrm{Rz} 1,4)$ "49. To wyrażenie w Liście do Rzymian zostało przełożone słowami: ,według Ducha Świętości”. Jak podają komentatorzy, to wyrażenie nie występuje w innych listach Pawłowych, a w tym miejscu oznacza swego rodzaju formułę odnoszącą się do Ducha Świętego, bardziej jednak stano-

\footnotetext{
${ }^{43}$ Cyrillus Hierosolymitanus, Catechesis 17, 4, PG 33, 971B, BOK 14, 278.

${ }^{44}$ Por. List do Rzymian, tłum., wstęp i koment. Langkammer, s. 106.

${ }^{45}$ Por. Katolicki komentarz biblijny, s. 1296.

${ }^{46}$ Cyrillus Hierosolymitanus, Catechesis 17, 4, PG 33, 971C, BOK 14, 278-279.

${ }^{47}$ Por. List do Rzymian, tłum., wstęp i koment. Langkammer, s. 104-105.

${ }^{48}$ Por. Katolicki komentarz biblijny, s. 1296.

${ }^{49}$ Cyrillus Hierosolymitanus, Catechesis 17, 5, PG 33, 973A, BOK 14, 279.
} 
wi „dynamiczne źródło świętości Jego uwielbionego stanu, dzięki któremu ożywia on ludzi" ${ }^{50}$. Należy ponadto dodać, że wyrażenie przytoczone przez biskupa Jerozolimy zostało wyrwane z kontekstu. Podany werset $(\operatorname{Rz} 1,4)$, podkreślający pochodzenie Jezusa Chrystusa według ciała, miał na początku listu zapowiedzieć, w jakim imieniu Rzymianie otrzymują list. Natomiast dla wiedzy katechumenalnej słuchaczy wystarczyło, by zrozumieli działanie Ducha Świętego, które obecne było w Jezusie Chrystusie.

Bezpośrednią kontynuacją powyższych słów Cyryla jest kolejne odniesienie do listu św. Pawła, z którego zaczerpnięte zostało inne określenie Ducha Świętego:

„Zwie się «Duchem synostwa», jak mówi Paweł: «Nie wzięliście Ducha niewoli, by ulegać bojaźni, lecz Ducha synostwa, w którym wołamy: Abba, Ojcze» $(R z 8,15)^{\prime 51}$.

„Duch synostwa” wprowadza relację między człowiekiem zbawionym przez Jezusa Chrystusa a Ojcem, gdyż do Niego odnosi się zawołanie „Abba”. Fakt Bożego synostwa oznacza także świadectwo postawy chrześcijanina ${ }^{52}$. Ten aspekt był dla katechety Jerozolimy istotnym momentem, gdyż uzmysławiał katechumenom duchowy stan, jaki zaistnieje w nich po przyjęciu chrztu.

Pod koniec Katechezy 17, która w całości została poświęcona nauce o Duchu Świętym, Cyryl zajął się Jego obecnością w duszach wierzących. Daje przykład Apostołów i wszystkich tych, którzy po nich przyjęli chrzest, ukazując u nich moc Jego działania. Uczynił to na podstawie kilku biblijnych odniesień, wśród których pojawił się także List do Rzymian. Nie podając żadnej wstępnej zapowiedzi, biskup dodaje: „I znowu: «Ten, który wzbudził Jezusa z martwych, ożywi i wasze śmiertelne ciała przez Ducha swego, który w was mieszka» (Rz 8, 11)"53.

Przytoczeniem tych słów Cyryl pragnie napełnić dusze słuchaczy optymizmem i radością eschatologiczną. Nawiązuje do wcześniej omawianego wątku dotyczącego ciała ludzkiego i jego znaczenia wówczas, gdy w nim zamieszka Duch Święty. Biskup, kończąc nauczanie o Duchu Świętym, wybiega myślą w przyszłość i podkreśla Jego ożywiające działanie w czasie zmartwychwstania chrześcijan.

4. Wymogi życia moralnego. Pierwszymi odniesieniami względem zasad życia moralnego są te cytaty z Listu do Rzymian, które dotyczą odpowiedzialności za czyny złe i dobre. Tę kwestię Cyryl poruszył w Katechezie 4 traktującej o głównych prawdach wiary, wśród których omówił także zagadnienie

\footnotetext{
${ }^{50}$ Katolicki komentarz biblijny, s. 1292.

${ }^{51}$ Cyrillus Hierosolymitanus, Catechesis 17, 5, PG 33, 973A, BOK 14, 279.

${ }^{52}$ Por. List do Rzymian, tłum., wstęp i koment. Langkammer, s. 107.

${ }^{53}$ Cyrillus Hierosolymitanus, Catechesis 17, 32, PG 33, 1005B, BOK 14, 292.
} 
duszy ludzkiej ${ }^{54}$. Zwraca uwagę na najbardziej charakterystyczną właściwość duszy, która jest wolna wola, gdyż jest ona odpowiedzialna za wszelkie czyny mające miejsce w życiu człowieka. Wyjaśnienie tej kwestii jerozolimski pasterz w taki sposób przedstawił słuchaczom:

„Wiedz też, iż zanim dusza przyszła na tę ziemię, nie miała żadnego grzechu.

Ale grzeszymy teraz wolną wolą. Nie słuchaj tego, który źle tłumaczy słowa: «To, czego nienawidzę - to czynię» $(\mathrm{Rz} 7,15)$ "s5.

Zagadnienie duszy ludzkiej i jej pochodzenia było częstym tematem podejmowanym zarówno przez myślicieli przedchrześcijańskich, jak i przedstawicieli wspólnot chrześcijańskich ${ }^{56}$. Cyryl wyznaje zasadę istnienia duszy najpierw czystej, tj. bezgrzesznej, ale z chwilą połączenia się z ciałem otrzymuje przywilej kierowania się wolną wolą. Katecheta w swym pouczeniu wybrał opcję negatywną, czyli skłonność duszy do wyboru zła - stąd jego stwierdzenie: ,grzeszymy teraz wolną wolą”. Tym sposobem przekonuje słuchaczy, że za zło w postaci grzechu odpowiedzialna jest wolna wola, która powinna umieć ustrzec się od niego. Dlatego dla poparcia swej argumentacji przywołuje krótki cytat z listu św. Pawła, wyjęty z dłuższego passusu poświęconego kwestii skłonności upadłej natury i walki duchowej pomiędzy wolą, świadomością zła i dobra oraz uwarunkowaniami ludzkiej natury. Zródłem takiego postępowania są grzeszne namiętności, które kryją w sobie pociąg do grzechu, poprzez co człowiek popada w grzech ${ }^{57}$.

Bezpośrednią kontynuacją tej tematyki i jednocześnie dalszym rozwinięciem podjętej kwestii jest odwołanie się do autorytetu św. Pawła, którego Cyryl cytuje bez wstępnego komentarza:

„I znów: «Jak oddawaliście członki wasze na służbę nieczystości i nieprawości, pogrążając się w nieprawości, tak teraz wydajcie członki wasze na służbę sprawiedliwości dla uświęcenia» (Rz 6, 19)"'58.

Powyższe słowa to dosłowny cytat z Listu do Rzymian. Cyryl, idąc za ideą św. Pawła, problem sprawności wolnej woli zilustrował przykładem zaczerpniętym z dziedziny czystości cielesnej. Ukazał wadliwe postawy w tym zakresie, jak nieczystość i nieprawość, co świadczy o wolnej woli prowadzą-

${ }^{54}$ Por. tamże 4, 18-21, PG 33, 477A - 481B, BOK 14, 67-69. Jest to zatem stosunkowo długi passus poświęcony duszy.

${ }^{55}$ Tamże 4, 19, PG 33, 480A, BOK 14, 68.

${ }^{56}$ Zob. niektóre opracowania dotyczące tego zagadnienia: C. Scanzillo, L'anima nei Padri dei primi secoli, w: L'anima, red. F. Battagla, Napoli 1979, 70-81; U. Bianchi, L'anima in Origene e la questione della metensomatosi, „Augustinianum” 26 (1986) 33-50; A.M. Filipowicz, Koncepcja duszy w pismach Tertuliana, Olecko - Warszawa 2007; R. Nakonieczny, Nauka o duszy w antropologii Dydyma Aleksandryjskiego, „Symbolae Philologorum Posnaniensium Graecae et Latinae” 21/2 (2011) 157-180.

${ }^{57}$ Por. Romaniuk, Soteriologia św. Pawła, s. 164.

${ }^{58}$ Cyrillus Hierosolymitanus, Catechesis 4, 19, PG 33, 480B, BOK 14, 68. 
cej do upadku duchowego. Św. Pawłowi zależy na świętości moralnej. Wyraził to zganieniem oddawania członków na służbę nieczystości, które na zasadzie pars pro toto obejmują całego człowieka, czyli jego egzystencję, władze duchowe, a nawet układ psychofizyczny, czyli całe jego bycie i postepowanie ${ }^{59}$. Tymczasem powinna pojawić się przeciwna postawa, prowadząca ku doskonałości, polegająca na mobilizacji członków służących sprawiedliwości w celu uświęcania.

Podstawą do podjęcia duchowego uświęcania jest wiara, która stała się przedmiotem refleksji w Katechezie 5. Cyryl przywołuje postacie biblijne, wśród których na pierwszym miejscu stawia Abrahama. Poświęca mu długi passus swego katechetycznego pouczenia, w którym trzykrotnie odwołuje się do Listu do Rzymian. O Abrahamie biskup tak się wypowiada:

„Można by wiele mówić o wierze - nawet cały dzień nie wystarczyłoby na to.

Ale niech na razie wystarczy przytoczenie z figur Starego Testamentu tylko

Abrahama, przez którego wiarę jesteśmy jego dziećmi (por. Rz 4, 11b) ${ }^{{ }^{\prime \prime 60}}$.

Biskup jerozolimski zdaje sobie sprawę, że tematyka wiary jest bardzo ważna w życiu chrześcijanina, wymagająca nieustannego pogłębiania i wzmacniania. Można by o niej mówić długo i szeroko, tak że nawet dnia by nie wystarczyło - jak zaznaczył. Tę kwestię wyjaśnia katechumenom, i to już w początkowej fazie ich przygotowania do przyjęcia chrztu. Proponuje, by bliżej przyjrzeć się sylwetce Abrahama i przeanalizować jego postawę wiary. Cyryl wzoruje się na św. Pawle, który także wybrał Abrahama w celu ukazania tzw. usprawiedliwienia przez wiarę ${ }^{61}$. Wprawdzie nie cytuje dosłownie słów Apostoła Narodów, ale jedynie przypomina tę postać, uświadamiając, że dzięki wierze Abrahama wszyscy stali się jego dziećmi. Dopiero w dalszej fazie opowiadania katechumenom o jego wielkości Cyryl nawiązuje do słów św. Pawła: „Bóg obiecał starcowi potomstwo i «Abraham nie zachwiał się w wierze» $(\mathrm{Rz} 4,19)^{\prime \prime 62}$. Wiara Abrahama, o której z naciskiem mówi św. Paweł, stała się warunkiem usprawiedliwienia ${ }^{63}$. Nawiązanie przez Cyryla do postaci Abrahama stanowi zasadnicze stwierdzenie tej katechezy, mające ukazać słuchaczom, na czym polega trwanie w sposób niezłomny w wierze.

Wśród ważnych pouczeń do nich kierowanych znalazło się wyjaśnienie relacji pomiędzy obrzezaniem a usprawiedliwieniem. Biskup dokonał tego w oparciu o wypowiedź św. Pawła, którą zapowiedział słowami:

„Ponieważ tu Abraham okazał się wierny, otrzymał znak jako pieczęć usprawiedliwienia: «Otrzymał znak obrzezania jako pieczęć usprawiedli-

${ }^{59}$ Por. List do Rzymian, tłum., wstęp i koment. Langkammer, s. 85.

${ }^{60}$ Cyrillus Hierosolymitanus, Catechesis 5, 5, PG 33, 512 A, BOK 14, 81.

${ }^{61}$ Zob. nieco starsze studium: K. Berger, Abraham in den paulinischen Hauptbriefen, „Münchener Theologische Zeitschrift" 17 (1966) 47-89.

${ }^{62}$ Cyrillus Hierosolymitanus, Catechesis 5, 5, PG 33, 512A, BOK 14, 81.

${ }^{63}$ Por. Stępień, Eklezjologia św. Pawła, s. 188-189. 
wienia osiagniętego z wiary, posiadanej wtedy, gdy jeszcze nie był obrzezany» (Rz 4, 11a)" ${ }^{64}$.

Powyższe słowa, którymi biskup obwieszcza katechumenom o zyskach, jakie Abraham otrzymał dzięki wierze, stanowią dosłowny cytat z Listu do Rzymian. Jak pisze, Abraham „otrzymał znak obrzezania”, będący ,pieczęcią usprawiedliwienia”. Św. Paweł powołuje się na Księgę Rodzaju, gdzie wiara Abrahama została mu poczytana za sprawiedliwość (por. Rdz 15), tymczasem obrzezanie nazwane zostało ,znakiem przymierza”, jakie Jahwe zawarł z rodziną Abrahama (por. Rdz 17, 11). Paweł jednak unika idei przymierza, a zamiast ,znaku przymierza” używa ,pieczęci usprawiedliwienia”, pokazując, że prawdziwe przymierze z Bogiem zawarte zostało z ludźmi wiary ${ }^{65}$. Stąd też Abraham nie jest ojcem obrzezanych, lecz ojcem duchowym nieobrzezanych, którzy poprzez wiarę w Jezusa Chrystusa dostępują łaski usprawiedliwienia ${ }^{66}$.

W kontekście wiary Cyryl przywołuje kolejne odniesienie do nauki św. Pawła. Swą zachętę do prowadzenia godnego życia motywuje kilkoma elementami, o których wspomina w Katechezie 7:

„Nie przed wiarą, lecz w następstwie wiary, dobrowolnie otrzymali godność dzieci Bożych. Skorośmy to poznali, pędźmy życie w duchu, abyśmy się stali godni dziecięctwa Bożego. «Wszyscy, których Duch Boży prowadzi, ci są synami Bożymi» (Rz 8, 14). Nic nam nie pomoże, iż otrzymaliśmy imię chrześcijan, jeżeli za tym nie pójdą uczynki" ${ }^{67}$.

Powyższa wypowiedź posiada dwóch adresatów. W części pierwszej Cyryl podsumowuje refleksję na temat postawy wiary u niektórych apostołów, wykazując, że ich wiara została najpierw zweryfikowana, by potem mogli otrzymać „godność dzieci Bożych”. Taki duchowy tytuł jest więc następstwem przyjętej wiary. W ten sposób biskup daje katechumenom przykład duchowej formacji wielkich osobistości, bo samych uczniów Chrystusa, aby podobną sytuację mogli zaakceptować u siebie. Stąd też drugą część tej wypowiedzi stanowią słowa kierowane bezpośrednio do słuchaczy, zawierające zachętę do skierowania swych wysiłków na prowadzenie życia w duchu, czyli pójścia droga duchowej doskonałości. Jeśli pojawi się u katechumenów tego typu duchowa postawa, dopiero wówczas można stać się „godnymi dziecięctwa Bożego”. Korzystając z listu św. Pawła, Cyryl uzupełnia swoje pouczenie jego zapewnieniem, że synami Bożymi są ci, których prowadzi Duch Boży ${ }^{68}$. Swego rodzaju pastoralnym zwieńczeniem tego wywodu jest stwierdzenie dotyczące istotowej zależności, a mianowicie - nabycie imienia chrześcijanina związane

${ }^{64}$ Cyrillus Hierosolymitanus, Catechesis 5, 5, PG 33, 512B, BOK 14, 81.

${ }^{65}$ Por. Katolicki komentarz biblijny, s. 1276.

${ }^{66}$ Por. List do Rzymian, thum., wstęp i koment. Langkammer, s. 58-59.

${ }^{67}$ Cyrillus Hierosolymitanus, Catechesis 7, 13-14, PG 33, 620B, BOK 14, 114.

${ }^{68}$ Autor katechez ponownie wykorzystuje w tym miejscu słowa z Rz 8, 14. Wyżej wypowiedź św. Pawła potrzebna mu była dla ukazania tytułu Ducha Świętego oraz tzw. usynowienia. 
jest z pełnieniem dobrych uczynków. W tym pouczeniu można dostrzec gradację intensyfikacji duchowego zaangażowania, będącego duchowym procesem w dążeniu do doskonałości chrześcijańskiej. Podstawą do osiągnięcia tej doskonałości są przede wszystkim dobre uczynki.

Istotną prawdę wiary, co już wyżej zaznaczono, biskup Jerozolimy omówił w Katechezie 15, w której odniósł się do spraw eschatologicznych, a ściślej - z osądzeniem żywych i umarłych. Odwołania do Listu do Rzymian pojawiają się w kontekście wypowiadania przestrogi związanej z przeciwnikiem duszy ludzkiej, czyli szatanem, biskup zachęca do walki z nim, mając na uwadze pomoc Chrystusa i dodaje: „Niech powie: «Któż nas odłączy od miłości Chrystusowej»? (Rz 8, 35)'”69. Biskup przytoczył werset z hymnu na cześć miłości Chrystusa, który wyzwolił człowieka od wszelkiego zła, jednocześnie obejmując miłosnym królowaniem ludzką egzystencję ${ }^{70}$. To pytanie apostoła domaga się natychmiastowej odpowiedzi i wówczas nikt i nic nie jest w stanie zagrozić wierności i oddania, jakie zawiera się w miłości. Takiego zachowania wymaga bowiem sytuacja zagrożenia aktywnością szatana, z czego zdaje sobie sprawę jerozolimski pasterz i dlatego nawołuje do wypowiadania słów o takiej treści.

Obok ostrzeżenia przed szatanem biskup Jerozolimy dalej zachęca do wytrwania w wierze, a także do przestrzegania zasad królestwa Bożego. Taka postawa polega na wystrzeganiu się negatywnych zachowań, które stają się bluźnierstwem. Dlatego biskup wprost oznajmia:

„Niech nie bluźnią z twej winy Chrystusowi! (por. Rz 2, 24) Noś szatę niewinności, odznaczając się dobrymi uczynkami! Jakiekolwiek otrzymałeś od Boga zadanie, spełnij je należycie!"’11

Zachęta do przestrzegania zasad, które swoim nauczaniem wprowadził Jezus Chrystus, została wypowiedziana przez biskupa w kontekście krytycznego ustosunkowania się Apostoła Narodów do postępowania Żydów. Czynność bluźnierstwa wobec Boga, o którym wspomniał św. Paweł, odnoszą się do negatywnych ich postaw wcześniej wymienionych w liście. Prosi więc Rzymian, aby ich postępowanie nie było podobne do tego, które prezentowali Żydzi ${ }^{72}$. Takim samym tokiem myślenia kierował się Cyryl, zamieniając jednak imię $\mathrm{Boga}^{73}$ na imię Chrystusa, namawiając swoich słuchaczy do godnego wypełniania zadań powierzonych przez Boga. Dobre uczynki, które powinni pełnić mający przyjąć chrzest, symbolicznie wyraża „szata niewinności”, będąca elementem wyobrażeniowym głoszonej katechezy.

\footnotetext{
${ }^{69}$ Cyrillus Hierosolymitanus, Catechesis 15, 16, PG 33, 892B, BOK 14, 227.

${ }^{70}$ Por. List do Rzymian, tłum., wstęp i koment. Langkammer, s. 117.

${ }^{71}$ Cyrillus Hierosolymitanus, Catechesis 15, 26, PG 33, 907C, BOK 14, 249.

${ }_{72}$ Por. List do Rzymian, tłum., wstęp i koment. Langkammer, s. 43.

${ }^{73}$ Słowa św. Pawła brzmią następująco: „Z waszej to bowiem przyczyny - zgodnie z tym, co jest napisane - poganie bluźnią imieniu Boga” (Rz 2, 24).
} 
Ten sam Pawłowy cytat Cyryl wykorzystał ponownie w Katechezie 23, będącej piątą katechezą mistagogiczną, w której omawia Mszę świętą. Jednak tym razem katecheta w sposób dosłowny przytacza werset z Listu do Rzymian, komentując prośbę z Modlitwy Pańskiej: „Święć się imię Twoje”! W tej kwestii naucza w ten sposób:

„Ponieważ jednak niekiedy grzesznicy Mu bluźnią jako napisane jest: «Z waszej winy poganie bluźnią imieniu Bożemu» (Rz 2, 24), dlatego prosimy, aby się święciło wśród nas imię boże" ${ }^{\text {"74 }}$.

Rada Cyryla skierowana do nowo ochrzczonych jest bardzo konkretna: pragnie, aby w swoim życiu czcili Imię Boga, a nie kierowali wobec Niego bluźnierstwa. W tym duchu chrześcijanie byli formowani od początku głoszenia Dobrej Nowiny, ponieważ wraz z nią komentowano Modlitwę Pańską. Zwracano więc głębszą uwagę na istotę imienia Bożego. Sam bowiem Jezus Chrystus pozwolił, aby świat poznał imię Jego Ojca, będąc dziedzicem imienia, czyli Jego Boskiej egzystencji ${ }^{75}$. Cyryl zatem także uwrażliwia swoich słuchaczy na ten element życia chrześcijańskiego, gdyż tym sposobem nie postępują jak poganie, którzy bluźnią.

Nawiązanie przez biskupa do szaty ma miejsce w pierwszej katechezie mistagogicznej (Katecheza 19), zawierającej wyjaśnienia dotyczące chrztu. Na jej zakończenie Cyryl, parafrazując myśl św. Pawła, tak dopowiada:

„Zdjąwszy starego człowieka, nie możesz się już smucić, lecz wdziawszy szatę zbawienia, Jezusa Chrystusa, obchodź dzień świąteczny (por. Rz 13, 14)"’76.

Cyryl parafrazuje myśl św. Pawła, który zapisał: „Ale przyobleczcie się w Pana Jezusa Chrystusa", co ma oznaczać, by Chrystus był zbroją, czyli dawał siły chrześcijanom do odsuwania grzechu. Przyobleczenie się w Chrystusa powinno przynieść ontologiczne utożsamienie się z Chrystusem, to znaczy większą świadomość ich chrześcijańskiej tożsamości ${ }^{77}$. Tymczasem biskup uzupełnił wypowiedź św. Pawła o bardziej wizualny element, tj. o szatę, którą jest Jezus Chrystus. Dopiero będąc w Niego przyobleczonym można „obchodzić dzień świąteczny". Prawdopodobnie był to dzień Zmartwychwstania Chrystusa i należało wyglądać odświętnie, także na duszy, gdyż słuchacze w przeddzień przyjęli chrzest.

Następstwa wynikające z przyodziania w szatę Cyryl wyjaśnił w drugiej katechezie mistagogicznej (Katecheza 20), także poświęconej rytom chrzcielnym. Opisał w niej związek chrześcijanina z Chrystusem i konsekwencje przyjęcia chrztu, co wyżej już zostało przedstawione. Na zakończenie tej katechezy biskup na zasadzie ekshortacji zwraca się do neofitów: „Mocen jest Bóg

\footnotetext{
${ }^{74}$ Cyrillus Hierosolymitanus, Catechesis 23, 12, PG 33, 1117B - 1120A, BOK 14, 341.

${ }^{75}$ Por. J. Szlaga, Imię Boże, II. W Piśmie Świętym, EK VII 61.

${ }^{76}$ Cyrillus Hierosolymitanus, Catechesis 19, 10, PG 33, 1075A, BOK 14, 322.

${ }^{77}$ Por. Katolicki komentarz biblijny, s. 1315.
} 
sprawić, abyście «wkroczyli w nowe życie» $(\mathrm{Rz} 6,4)$ "78. To wezwanie, które jest częścią dłuższej zachęty, przybiera znamiona modlitwy biskupa za nowo ochrzczonych. Elementem tej modlitwy są także słowa zaczerpnięte z listu św. Pawła. Wyrażenie „nowe życie” jest nawiązaniem do faktu zmartwychwstania Chrystusa, tj. przejścia z martwych do życia, a więc nabycia nowego statusu ${ }^{79}$.

Następna mowa skierowana do neofitów, czyli Katecheza 21, rozpoczyna się właśnie nawiązaniem do nauczania św. Pawła. Biskup Jerozolimy kieruje bowiem do nich słowa:

„W Chrystusie ochrzczeni i w Chrystusa przyobleczeni staliście się podobni do Syna Bożego (por. Rz 6, 5)" ${ }^{\prime 80}$.

W tym stwierdzeniu zostały wypowiedziane dwie istotne kwestie odnoszące się do duchowości chrześcijańskiej nowo ochrzczonych, będące jednak przypomnieniem wcześniej przez nich usłyszanych pouczeń. Cyryl powtórzył bowiem te idee, by mógł w tej katechezie przystapić do omawiania drugiego sakramentu, którym jest bierzmowanie. A zatem w kolejnym dniu biskup zaakcentował fakt, że przyjęty chrzest dokonał się w imię Chrystusa, a konsekwencją tego jest przyobleczenie się w Niego - co już wyżej szerzej zostało omówione. Również druga idea - powtórnie wymieniona w tej katechezie obwieszcza z kolei myśl o podobieństwie do Chrystusa, co katecheta wyjaśnia w nawiązaniu do listu św. Pawła (por. Rz 6, 5). Z tego bogatego w idee teologiczne wersetu ${ }^{81}$ Cyryl wybrał jedynie jedno słowo: „podobni”. O podobieństwie do Syna Bożego w kontekście Jego śmierci i zmartwychwstania także wyżej więcej podano słów komentarza. Przez to ograniczenie treściowe biskup z pewnością chciał skupić się nie na aspekcie chrystologicznym, lecz uwypuklić duchową sferę słuchaczy, zachęcając do kierowania się w życiu innym wizerunkiem moralnym.

Wezwanie do prowadzenia chrześcijańskiej moralności obecne jest w całej Katechezie 21. Dla zobrazowania przyjęcia przez neofitów nowej duchowej rzeczywistości w kontekście bierzmowania Cyryl wykorzystał wypowiedź św. Pawła:

„bo rzeczywiście zostaliście namaszczeni przez Ducha Świętego. Początkiem waszego zbawienia jest Chrystus - On jest zaczynem, wy ciastem. Gdy zaczyn jest święty, i ciasto jest święte (por. Rz 11, 16)"\$2.

Cyryl najpierw podaje myśl teologiczna, a potem jej ilustrację istniejącą w świecie materialnym. Naucza zatem, że źródłem zbawienia człowieka

${ }^{78}$ Cyrillus Hierosolymitanus, Catechesis 20, 8, PG 33, 1084B, BOK 14, 328.

${ }^{79}$ Por. Zdziarstek, Chrystianologia św. Pawła, s. 95.

${ }^{80}$ Cyrillus Hierosolymitanus, Catechesis 21, 1, PG 33, 1088A, BOK 14, 331.

${ }^{81}$ Brzmi on następująco: „Jeżeli bowiem przez śmierć, podobną do Jego śmierci, zostaliśmy z Nim złączeni w jedno, to tak samo będziemy z Nim złączeni w jedno przez podobne zmartwychwstanie" (Rz 6, 5).

${ }^{82}$ Cyrillus Hierosolymitanus, Catechesis 21, 6, PG 33, 1093A, BOK 14, 333. 
jest Chrystus. Zbawienie następnie zostaje utrwalone przez działanie Ducha Świętego. Obraz zaczynu i ciasta katecheta jerozolimski przejął od św. Pawła, który napisał: „Jeżeli bowiem zaczyn jest święty, to i ciasto” (Rz 11, 16). W ten sposób Cyryl utwierdził w duszach nowo ochrzczonych znamię świętości, ponieważ otrzymali je od Chrystusa, który jest święty. Ten obraz został przejęty z obrzędów kultycznych Starego Testamentu, gdzie poprzez ofiarowanie Bogu pierwocin z zebranego żniwa nastąpiło uświęcenie całego pożywienia. Akt ofiarowania był połączony z intencją, aby Jahwe błogosławił każde pożywienie ${ }^{83}$.

Innym sposobem zadbania o świętość jest unikanie grzechu. Korzystając z autorytetu św. Pawła, Cyryl w Katechezie 23, w której wyjaśnił obrzędy i teologię Mszy świętej, przytoczył jego myśl. Uczynił to w kontekście komentowania prośby z Modlitwy Pańskiej - „Przyjdź Królestwo Twoje” w następującym pouczeniu:

„Kto słyszy wypowiedź Pawła: «Niech grzech nie panuje w waszym śmiertelnym ciele» $(R z 6,12)$ i czysty jest w czynie, myśli i mowie, ten mówi do Boga: «Przyjdź Królestwo Twoje»" ${ }^{44}$.

Biskup Jerozolimy czystość duszy, która nie jest skalana grzechem, ujmuje w przyjętej już wówczas formie obecnej w akcie pokutnym, czyli w odniesieniu do trzech kategorii: czynu, myśli i mowy. To oznacza, że owa czystość powinna być całkowita. Dopiero wówczas chrześcijan jest godny tego, aby do Boga skierować prośbę o nadejście Królestwa Bożego. Biskup potwierdzenia takiego podejścia odnalazł w liście św. Pawła, który swego czasu zwracał się do Rzymian, by w ich śmiertelnym ciele nie panował grzech. Mimo bowiem przyjęcia chrztu i uwolnienia od grzechu, owa wolność nie okazała się ostateczna, a chrześcijanin może ciagle ulegać oszustwom grzechu ${ }^{85}$.

Dokonane analizy porównawcze odnoszące się do wypowiedzi Cyryla, w których umieścił idee św. Pawła z jego Listu do Rzymian, układają się w logiczny ciąg zagadnień teologicznych. Otóż przedstawiają naukę, kierowaną do słuchaczy w jerozolimskiej bazylice, wyjaśniającą udział w zbawczym procesie Trzech Boskich Osób oraz wynikający z tego moralny udział chrześcijanina w tym dziele zbawczym. W odniesieniu do Boga Ojca biskup zachęcał swoich słuchaczy do otwartości na Niego i dążenie do poznania Go poprzez refleksję nad światem stworzonym. Jezusowi Chrystusowi poświęcił bardzo wiele miejsca $\mathrm{w}$ katechezach, zwracając uwagę na poszczególne aspekty Jego Osoby. Jest On bowiem kamieniem, na którym można budować

\footnotetext{
${ }^{83}$ Por. List do Rzymian, tłum., wstęp i koment. Langkammer, s. 146-147.

${ }^{84}$ Cyrillus Hierosolymitanus, Catechesis 23, 13, PG 33, 1120A, BOK 14, 342.

${ }^{85}$ Por. Katolicki komentarz biblijny, s. 1288.
} 
nadzieję, a także chroni chrześcijan przed atakami szatana. Biskup przedstawił znaczenie wcielenia i sens ukrzyżowania, ukazując ich cele: zmartwychwstanie, osąd żywych i umarłych oraz wieczne królowanie Jezusa Chrystusa. Zwrócił uwagę na skutki przyjęcia chrztu, w którym otrzymuje się nowe życie i udział w zmartwychwstaniu. Duch Święty został opisany jako Pocieszyciel, dający radość i nadzieję skierowaną na wartości wieczne. Duch Święty daje ochrzczonym moc wewnętrzną oraz udział w synostwie Bożym. Przekaz nauki o Bożych Osobach bezpośrednio łączył się z wysłuchaniem przez nowo ochrzczonych zasad postępowania $\mathrm{w}$ duchu chrześcijańskim. Powinna ich cechować odpowiedzialność za czyny dobre i złe, przy zwróceniu uwagi na rolę wolnej woli. Katecheta podkreślił, że podstawą dobrego postępowania jest wiara i pełnienie dobrych uczynków. To wynika z faktu przyobleczenia w szatę Jezusa Chrystusa, a konsekwencją tego jest święcenie imienia Bożego i unikanie grzechu.

\section{EPISTLE TO THE ROMANS IN THE CATECHESIS OF CYRIL OF JERUSALEM. WAYS OF USE AND INTERPRETATION}

\section{(Summary)}

Cyril of Jerusalem, the author of the Catechesis delivered to the catechumens and the newly baptized, gave the teachings of Jesus Christ on the basis of the Symbol in force in Jerusalem, and above all on the basis of the Holy Scriptures. He readily referred to the books of the Old and New Testaments, quoting literal citations or paraphrasing individual biblical ideas. Among the frequently quoted biblical books is also the St. Paul's Epistle to the Romans, which was used by Cyril almost 40 times. Some of Paul's statements were used as an element of the content link, while others are the starting point for presenting the wider context of Christian teachings to the audience. In most cases, these are literal quotes from the Letter to the Romans. It turns out that the statements of the Apostle of Nations constitute the basis for the interpretation of mainly the Trinitarian aspects of the Christian faith, because individual references serve to bring the listeners closer to the Three Divine Persons. Other quotes Cyril also uses to present some issues of Christian morality.

Key words: Cyril of Jerusalem, Catechesis, Saint Paul, Epistle to the Romans, Trinitarian aspects, issues of Christian morality.

Słowa kluczowe: Cyryl Jerozolimski, Katechezy, św. Paweł, List do Rzymian, aspekty trynitarne, kwestie moralności chrześcijańskiej. 


\section{BIBIOGRAFIA}

\section{Źródła}

Cyrillus Hierosolymitanus, Catecheses, PG 33, 331-1057, tłum. W. Kania: Św. Cyryl Jerozolimski, Katechezy przedchrzcielne i mistagogiczne, BOK 14, Kraków 2000.

\section{Opracowania}

Berger K., Abraham in den paulinischen Hauptbriefen, „Münchener Theologische Zeitschrift" 17 (1966) 47-89.

Bianchi U., L'anima in Origene e la questione della metensomatosi, „Augustinianum” 26 (1986) 33-50.

Filipowicz A.M., Koncepcja duszy w pismach Tertuliana, Olecko - Warszawa 2007.

JanKowski A., Eschatologia biblijna Nowego Testamentu, Kraków 1987.

JAŚKIEWICZ G., Doketyzm jako wyraz relatywizmu w teologii, Ząbki 2011.

JAŚKIEwICZ G., Polemika antydoketystyczna u św. Ignacego z Antiochii, „Studia Ełckie” 13 (2011) 401-408.

Katolicki komentarz biblijny, red. W. Chrostowski, Warszawa 2001.

Lamarche P., Kamień, w: Stownik teologii biblijnej, red. X. Leon-Dufour, tłum. K. Romaniuk, Poznań - Warszawa 1982, 360.

LangKammer H., Hymny chrystologiczne Nowego Testamentu. Najstarszy obraz Chrystusa, Katowice 1976.

List do Rzymian, tłum., wstęp i koment. H. Langkammer, Lublin 1999.

McDonnell K. - Montague G.T., Inicjacja chrześcijańska a chrzest w Duchu Świętym, tłum. M. Górnicki - W. Kustra, Kraków 1997, 270-272.

Nakonieczny R., Nauka o duszy w antropologii Dydyma Aleksandryjskiego, „Symbolae Philologorum Posnaniensium Graecae et Latinae" 21/2 (2011) 157-180.

Pesch R., Römerbrief, Würzburg 1983.

Romaniuk K., Soteriologia św. Pawła, Warszawa 1983.

Scanzillo C., L'anima nei Padri dei primi secoli, w: L'anima, red. F. Battagla, Napoli 1979, 70-81.

Schlier H., Die Taufe nach dem 6. Kapitel des Römerbriefen (Die Zeit der Kirche), Freiburg 1966.

StęPIEŃ J., Eklezjologia św. Pawła, Poznań - Warszawa - Lublin 1972.

Szlaga J., Imię Boże, II. W Piśmie Świętym, EK VII 61.

Widok N., Polemika antyheretycka w „Katechezach” Cyryla Jerozolimskiego, VoxP 37 (2017) t. 68, 423-442.

Widok N., Wiara - miłość - nadzieja. Studium w oparciu o listy Ignacego z Antiochii, Opole 2011.

Zdziarstek R.S., Chrystianologia św. Pawła, t. 1: Aspekt ontologiczny, Kraków 1989. 
